\title{
COMBINATION OF UNDECYLENIC ACID AND CHEMICALS FROM ASH OF DESEEDED FRUIT HEAD OF OIL PALM ENHANCES UNDECYLENIC ACID ANTI- FUNGAL ACTIVITY AND IS ANTI-BACTERIAL
}

\author{
Iroka J Udeinya ${ }^{1}$, Ngozi F Onyemelukwe ${ }^{2}$, B A Uzodimma ${ }^{2}$, Florence I Udeinya ${ }^{3}$, Elvis N Shu ${ }^{1}$, \\ Nkoyo I Nubila ${ }^{1}$, Uzoamaka A Okoli ${ }^{4}$, Tochukwu M Okafor ${ }^{1}$
}

\section{${ }^{I}$ PHARMACOLOGY AND THERAPEUTICS, University of Nigeria, Nigeria, ${ }^{2}$ Department of Medical Laboratory Sciences, University of Nigeria, Nigeria, ${ }^{3}$ Rocitus Institute of Research, Enugu, Nigeria, ${ }^{4}$ Department of Medical Biochemistry, University of Nigeria, Nigeria}

An Oil Palm Ash Chemical (OPAC) was obtained by heating to dryness the filtrate of soaked ash of deseeded fruit-head of oil palm bunch. OPAC solution $(0.3 \mathrm{gm} / \mathrm{ml}, \mathrm{pH} 10-12)$, was mixed in a 1:1 ratio by volume with undecylenic acid (UA) a known antifungal agent, to form UNDOPAC with a $\mathrm{pH}$ of 8-9. Antifungal and antibacterial effects of UNDOPAC and UA were investigated invitro.

UNDOPAC dissolved in phosphate buffered saline PBS was tested for anti-fungal activity at the following concentrations, $0.5 \mathrm{ug} / \mathrm{ml}, 1.0 \mathrm{ug} / \mathrm{ml}, 5.0 \mathrm{ug} / \mathrm{ml}, 10.0 \mathrm{ug} / \mathrm{ml}, 15.0 \mathrm{ug} / \mathrm{ml}, 20.0 \mathrm{ug} / \mathrm{ml}$ and $25.0 \mathrm{ug} / \mathrm{ml}$, using five fungal isolates; C. albicans, T. rubrium, T. mentagrophytes, E. flocosum and M. gypseum. UA was also tested at the same concentrations against the same isolates. UNDOPAC was additionally tested for anti-bacterial activity using three bacterial isolates; P aeruginosa, $\mathrm{S}$. aureus and E.coli at concentrations of $1 \mathrm{ug} / \mathrm{ml}, 5 \mathrm{ug} / \mathrm{ml}$ and $25 \mathrm{ug} / \mathrm{ml}$.

Tests were carried out by culturing fungal and bacterial isolates for 96 hours on agar plates embedded with test substances, PBS (positive controls). Negative controls were agar plates incubated without inoculating with any isolate. Three separate experiments were performed (for each isolate $n=3$ ), each in triplicates. Growth in cultures were visually assessed and diameter of growth scored from 0 to $10+$, where 0 is no observable growth and $10+$ taken as maximal observable growth (as observed in the negative and positive controls respectively). Descriptive statistics were employed for data analysis using Statistical Package for Social Sciences version 21.

UA growth score of 0 was recorded at $10 \mathrm{ug} / \mathrm{ml}$ and above for C. albicans, $1 \mathrm{ug} / \mathrm{ml}$ and above for T. rubrium, T. metagrophytes and $\mathrm{T}$ flucossum, and at $0.5 \mathrm{ug} / \mathrm{ml}$ and above for $\mathrm{M}$. gypseum. However, UNDOPAC revealed better antifungal effect with a growth score of 0 recorded at $0.5 \mathrm{ug} / \mathrm{ml}$ and above for all the five fungal isolates. In addition, all three bacterial isolates showed no observable growth at $25 \mathrm{ug} / \mathrm{ml}$. UNDOPAC has a lower MIC than UA alone indicating a more efficacious anti-fungal activity superior to UA, and is antibacterial. Such activity combined with its reduced skin irritation recommends UNDOPAC as possible alternative to UA in a variety of topical application 